\title{
Corporate Social Responsibility, Firm Value, and Financial Constraints: A Signal of Corporate Liquidity
}

\author{
Maria Yosaphat Dedi Haryanto ${ }^{1,2, *}$, Anis Chariri $^{3}$, Etna Nur Afri Yuyetta ${ }^{3}$ \\ ${ }^{1}$ Doctoral Program, Faculty of Economics and Business, Universitas Diponegoro, Indonesia \\ ${ }^{2}$ Faculty of Business and Accounting, Universitas Katolik Musi Charitas, Indonesia \\ ${ }^{3}$ Faculty of Economics and Business, Universitas Diponegoro, Indonesia
}

Received July 31, 2021; Revised September 29, 2021; Accepted October 17, 2021

\section{Cite This Paper in the following Citation Styles}

(a): [1] Maria Yosaphat Dedi Haryanto, Anis Chariri, Etna Nur Afri Yuyetta, "Corporate Social Responsibility, Firm Value, and Financial Constraints: A Signal of Corporate Liquidity," Universal Journal of Accounting and Finance, Vol. 9, No. 6, pp. 1322 - 1331, 2021. DOI: 10.13189/ujaf.2021.090611.

(b): Maria Yosaphat Dedi Haryanto, Anis Chariri, Etna Nur Afri Yuyetta (2021). Corporate Social Responsibility, Firm Value, and Financial Constraints: A Signal of Corporate Liquidity. Universal Journal of Accounting and Finance, 9(6), 1322 - 1331. DOI: 10.13189/ujaf.2021.090611.

Copyright@2021 by authors, all rights reserved. Authors agree that this article remains permanently open access under the terms of the Creative Commons Attribution License 4.0 International License

\begin{abstract}
The concept of corporate social responsibility (CSR) has gained much attention and has been currently practiced by many companies. This study examined the role of CSR disclosure as a signal on the corporate liquidity in creating value for the firms. We examined the effects of moderation using subgroup analysis on a sample of 77 manufacturing sector firm that listed on IDX with three years data observations. By using the Chow test, the results show that CSR disclosure is related with firm value in non-financial constraints (NFC) firms compared to financial constraints (FC) firms. However, the two groups of companies have opposite effects. Companies with non-financial constraints have a positive direction while the other group has no specific pattern for the FC sample. The empirical evidence showed that firms with financial constraints report less information about their CSR activities than firms with non-financial constraints. Our findings suggest that company with non-financial constraints can confidently and strategically increase CSR investment to enhance firm value. However, the company with financial constraints needs to carefully examine the effects of CSR on firm value when making CSR-related decisions.
\end{abstract}

Keywords Corporate Social Responsibility Disclosure, Financial Constraints, Firm Value, Liquidity

\section{Introduction}

Mandatory and voluntary Corporate Social Responsibility (CSR) disclosures can make a difference in nature and extent of reporting between companies. From time to time, each country issues mandatory reporting provisions including disclosure regulations that result in increasing numbers of disclosures becoming more diverse in each country [1]. In Indonesia, CSR activities have begun to be regulated in UU No.40/ 2007 concerning Limited Companies. Article 74 paragraph 1 states that limited companies that conduct business in the field and/or concerned with natural resources are required to carry out social and environmental responsibilities. Another regulation that incorporates CSR is UU No.25/ 2007 at Article 15 (b). This act states that every investor is obliged to carry out social responsibility. However, the act has not yet confirmed how companies must report CSR activities until the government issues Government Regulation No. 47 of 2012 concerning Corporate Social and Environmental Responsibility. Article 6 of this regulation requires the implementation of social and environmental responsibility to be contained in the Company's annual report and accounted for the General Meeting of Shareholders. That year has become a milestone for CSR reporting requirements for corporate companies. Not much research has focused on the effects of disclosure in the early days of CSR reporting. In addition, this study wants to contribute to how the effects 
of CSR disclosure at the time of reporting regulations are issued.

At present, CSR has developed as a corporate strategy to maintain business continuity. It can be said that CR reporting has become a major business practice worldwide. According to the ${ }^{\mathrm{KPMG}}$ [2] Survey, almost three-quarters (71 percent) of the 4,100 companies surveyed reported CSR. Other findings show that Corporate Responsibility (CR) reporting in the Asia Pacific has increased dramatically over the past two years. Nearly three-quarters (71 percent) of the companies based in the Asia Pacific now publish CR reports, an increase of 22 percent since 2011 when less than half ( 49 percent) did so. The highest CR growth since 2011 was seen in India (+53 percent), Chile (46), Singapore (37), Australia (+25), Taiwan (+19) and China $(+16)$. Besides, more than half percent $(51$ percent) of companies disclose CR information in their annual financial statements. This is a drastic increase since 2011 (when only 20 percent did it) and 2008 (only 9 percent). The direction of development of CR is now more visible because some companies now disclose CR data in their financial statements. Therefore, this can be considered a global standard practice.

CSR disclosure is a means for companies to communicate CSR efforts that have been carried out both mandatorily and voluntarily. Companies express CSR because stakeholders care about social and environmental issues [3]. Companies allocate considerable resources to disclose extensive information about CSR issues either in annual reports or in self-contained reports such as Sustainability Reports. Research conducted by Hill et al. [4] found that in the long run, companies committed to CSR experienced a very significant increase in share prices compared to companies that did not practice CSR. Bajic \& Yurtoglu [5] who used a sample from 35 countries over the 2003-2016 period found a significant economically relationship between the overall size of CSR and firm value. Whereas in Japan, Kumarasinghe et al. [6] research found that the more companies disclose CSR about labor, human rights and product safety and health in the company's annual report, the more it results in higher levels of financial performance and market performance. But on the contrary, research by Crisostomo et al. [7] through the estimation of econometric models shows the tendency of negative CSR effects on firm value in Brazil. Likewise, Jitmaneeroj [8] who used US company data between 2002 and 2014 found inconsistent evidence of the direct relationship between each CSR proxy and firm value. The relationship between CSR and corporate values is still inconclusive and varies between countries.

In Indonesia, which is a developing country, CSR research on firm value also shows inconsistent results. Gunawan and Utami [9] prove that CSR disclosure has a positive impact on the company's value in the future. Likewise,, Rustiarini [10], and Murwaningsari [11] concluded that the long-term stability and prosperity of the company can be obtained if the company carries out social responsibility of the community. But the opposite results are shown by research by Nurlela and Islahuddin [12], and Tjia and Setiawati [13]. Their research concluded that disclosure of Corporate Social Responsibility does not affect the value of the firm. The results of this study show a variety of relationships ranging from positive, negative or no relationships at all. Hence, the direction of the research is still on whether there is a relationship between CSR reporting with firm value but most are not able to reveal how the relationship is [14].

Most prior research has focused on the relationship between CSR initiatives and corporate value that result in inconsistent findings. This phenomenon provides an incomplete understanding of the relationship and triggers the existence of potential contingency factors. Although it is still limited, some researchers have begun to look for the causes of these inconsistent relationships. Several studies prove the existence of contingency factors such as industry, company status and family ownership [15 - 16]. Lee and Park [15] shows that hospitality company CSR in Korea has a simultaneous and positive relationship with financial performance both profitability and firm value, but for casino companies, the results show CSR does not have a simultaneous effect on financial performance. In China, Liu and Zhang [16] show that the effect of disclosure CSR information is significantly negative to the company's long-term value, but when interacting with the company's status, the results are different, namely interactive between CSR disclosure and state-owned companies showing positive signs, while the Central and Western regions (AREA) results in negative interactions. In France, Nekhili et al. [17] show that financial performance market-based ideas, measured by Tobin's q, are positively related to CSR disclosures for family businesses but negatively related to CSR disclosures for non-family firms.

We use financial constraints as a contingency factor. We believe that there are similarities in the perspectives of shareholders and stakeholders in viewing CSR. External parties viewed the CSR program as an investment decision taken by the manager. This investment decision is related to financing factors which in the long run can affect company liquidity. Empirical evidence shows a link between investment decisions and funding decisions. Early research Fazzari et al. [18]; Vogt [19]; Kaplan \& Zingales [20]; Cleary [21]; Almeida et al. [22] find that there is a relationship between liquidity and company investment decisions in the United States. The same result was discovered by Hoshi et al. [23] in Japan.

CSR initiatives are a corporate strategy and part of an investment decision. The company's ability to implement CSR and disclose it to the public is a sign that the company has financial strength, especially internal financing. Therefore, external parties will capture CSR 
disclosure as a signal of corporate liquidity. When companies have financial constraints, the effect of CSR disclosure on firm value will be weaker. Conversely, when companies have internal financial strength (financial flexibility), the impact of CSR disclosure will be stronger for the value of the firm. This study aims to investigate that financial constraints can influence the relationship between CSR disclosure and firm value. This research has the following contributions. First, this study wants to examine that companies use CSR disclosure as a signal of corporate liquidity. Second, this study shows that companies with financial constraints must examine the effect of CSR disclosure on the value of their company when they make decisions about CSR. Third, understanding the moderating effects of financial constraints on CSR disclosure not only helps to put a conclusion on the CSR literature in the right context but also provides new insights into appropriate CSR issues.

\section{Literature Review}

\subsection{Signaling and Corporate Social Responsibility}

For public companies, effective and appropriate signals enable them to improve their performance in the capital market [24]. The signal can be in the form of positive and trustworthy information reducing uncertainty about the company's prospects to increase the company's credibility and success. In signaling theory, a signal is effective if it has two central premises namely the signal must be observable or known in advance, and the signal must be expensive or difficult to replicate. CSR is a real activity at the same time expensive and difficult to imitate because CSR is an investment decision for managers whose implementation requires resources and sources of funds. Companies that have financial constraints or financial constraints will find it difficult to maintain CSR programs in the long run. CSR implementation has an impact on company liquidity.

Disclosure of social responsibility by the company is expected to increase the value of the firm and be a signal about the company's concerns and prospects going forward to external parties. Ball and Brown [25] state that changes in stock prices move under investor expectations so that it will affect the behavior of investors in making decisions. The valuable information is the company's CSR disclosure, while investor's behavior is the investor's response to the announcement of the company's annual report. Research that links CSR disclosures to corporate value is conducted by Rustiarini [10], Murwaningsari [11], and Andayani et al. [26]. Their research supports the hypothesis that the level of disclosure of CSR information in the company's annual report increases the value of the firm.

Through CSR activities, companies contribute to economic development and improve the quality of life of their workforce, their families, the local community and the wider community. In their meta-analysis of a large number of academic studies, Orlitzky et al. [27] found a positive relationship between CSR performance and financial performance. CSR activities are likely to improve financial performance through various channels such as improving the brand image improve relations with regulators and relations with creditors [28 - 30].

Cheng et al. [30] examined whether CSR strategies affect a company's ability to access finance in the capital market. Although it has been debated in the past which CSR can impose unnecessary costs on a company that can hamper its ability to access capital. The results of their research are the opposite: companies with better CSR performance face lower capital constraints. This negative relationship between CSR performance and capital constraints is manifested through the explanation that companies with better CSR performance will more openly disclose their CSR activities and consequently become more transparent and accountable [31]. A higher level of transparency reduces information asymmetry between companies and investors, thereby reducing perceived risk. Also, companies with better CSR performance who prefer to disclose their CSR activities to the market can be a differentiator with others [32].

\subsection{Investment Decision and Liquidity}

Investment decisions are an important factor in the company's financial function. Fama [33] states that the value of a company is solely determined by investment decisions. This opinion can be interpreted that the investment decision is important because it relates to achieving the company's goals, namely maximizing the prosperity of shareholders. Theodoulidis et al. [34] provide useful insights that the way stakeholder management practices, which are expressed as CSR activities, interact with corporate strategy and corporate financial performance. The investment decision in this study is capital expenditure for CSR activities.

The decision to allocate capital to investment proposals whose benefits will be realized in the future must be carefully considered. As a result of uncertainty in the future, the benefits obtained will be uncertain, so the investment proposal contains risks. Consequently, investment proposals must be evaluated and linked to the risks and expected outcomes. Villarón-Peramato et al. [35] obtained evidence that is confirmed in the context of asymmetric information, limited rationality, and different interests, the use of debt as a control mechanism for the looseness of manager's policies. In other words, CSR practices can be used by managers as a defense and self-defense strategy to reduce the possibility of being identified by shareholders and stakeholders whose interests have been damaged. 
According to Modigliani and Miller [36], in perfect market conditions there is no relationship between investment decisions and funding decisions. However, empirical evidence shows the relationship between investment decisions and funding decisions. In this case, there is a relationship between the level of liquidity and the level of investment in many companies. Moyen [37] shows that there is a relationship between liquidity and investment decisions in companies in the United States. Empirical evidence in Indonesia is shown by Agung [38], Kristianti [39], Deni et al. [40] and Hermeindito [41] who find that liquidity is positively related to investment decisions. In contrast, Prasetyantoko [42] in his research showed that liquidity is negatively related to investment decisions.

\subsection{Financial Constraints}

Financial constraints are the company's limitations in getting capital from sources of funding available to invest. Kaplan and Zingales [20] state that financial constraints occur when companies face the difference between capital costs from internal funding sources and capital costs from external funding sources. Basically, company managers prefer to use internal funds to finance investment. Investment decisions to use internal funds can avoid oversight from shareholders or external parties [43]. Companies that have a financial constraint mean having financial constraints to make investments. Companies with financial constraints have a high sensitivity to internal funding [18]. Conversely, companies that do not have financial constraints have high financial flexibility and are easier to use external funding sources because they have access to more open markets [44, 45].

In implementing CSR strategies, companies will face funding problems because CSR programs are investment decisions that require funding. If not managed properly, it will certainly be able to disrupt the company's liquidity. Bhandari and Javakhadze [46] found that the effect of CSR distortion on investment sensitivity to firm value is stronger for companies with incongruent shareholder-manager incentives. But in the long run CSR programs can maintain company liquidity. Hidayat [47] shows that liquidity and investment opportunities have a positive effect on investment decisions. Furthermore, liquidity is more influential in investment decisions in companies with financial constraint (FC) than companies with non-financial constraints (NFC). This is due to the asymmetry of information on external funding, so that external funding such as debt is more expensive than internal funding, which results in financial constraint companies having less access to external funding sources. This shows that financial constraint's investment decisions are more sensitive to liquidity.

Hermeindito [41] shows that corporate investment decisions are more sensitive to liquidity in financially constrained companies, compared to non-financially constrained companies. Instead, Kristianti [39] found that corporate investment decisions are more sensitive to liquidity in NFC firms than FC firms. Financial constraints occur when companies face the difference between capital costs from internal funding sources and capital costs from external funding sources. Management's decision to carry out CSR activities is often constrained by funding. Companies that experience financial constraints will try to attract the attention of stakeholders by disclosing CSR activities, but the effect on company value can be the opposite because CSR provides information about the company's liquidity and sustainability. Based on the explanation above, we hypothesize that CSR disclosure is more influential in firm value in NFC firms compared to FC firms.

\section{Research Method}

\subsection{Sampling}

This study use company listed on the Indonesia Stock Exchange (IDX). To avoid industrial effects, the researchers only examined one sector, the manufacturing sector. Initial sample consist of 88 firms from manufacturing sector companies listed on the IDX for 2012 to 2014. Researchers consider using these three years observation from 2012 to 2014 because in Indonesia regulations regarding CSR reporting were issued in 2012 through Government Regulation No. 47 of 2012 that companies are required to include CSR reports in their annual reports. The final sample was 77 companies after elimination to meet the requirements of classical assumptions during data analysis. The study is based on secondary data collected from the annual report in IDX and other sources such as the Indonesian Capital Market Directory (ICMD) for financial data and stock prices. All data are obtained from the Indonesian Stock Exchange website.

\subsection{Variables and Measurements}

The independent variable is Corporate Social Responsibility Disclosure. CSR disclosure is the extent of information about social, environmental and community activities. CSR disclosure is measured by the CSR index. The CSR Index uses an initial version of the GRI guidelines, namely the G3. The CSR information in the annual report will be compared with 79 indicators from G3.0. CSDI calculations use dichotomous procedures, where each CSR item in the research instrument is given a value of 1 if disclosed, and a value of 0 if not disclosed [46]. Next, the scores of each item are added together to get the overall score for each company. The CSDI calculation formula is as follows: 


$$
\operatorname{CSDI}_{\mathrm{j}}=\frac{\sum X_{l j}}{\mathrm{n}_{\mathrm{j}}}
$$

where:

CSDI $_{\mathrm{j}: \text { : }}$ Corporate Responsibility Disclosure Index

$n_{\mathrm{j}}$ : number of items expected for the company, $\mathrm{nj}=79$ items; and

$\mathrm{X}_{\mathrm{ij}}$ : of " 1 " if the company discloses the items, and " 0 " if it does not.

The dependent variable is firm value. This variable uses market value because it reflects shareholders' expectations of the company's future performance [48]. Firm value is measured by Tobin's Q because of its ability to capture long-term, intangible investment values [49]. Tobin's $Q$ is also a comprehensive performance measure because it combines several aspects of company performance such as earnings, sales, cash flow and revenue volatility so that it becomes more objective in valuing the company [49]. Tobin's $\mathrm{Q}$ is calculated using the following formula:

Tobin's $\mathrm{Q}=(\{(\mathrm{CP} \times$ Number of Shares $)+\mathrm{Tl}+\mathrm{I})\}-\mathrm{CA})$ I TA.

Where: $\mathrm{CP}=$ Closing Price, $\mathrm{TL}=$ Total Liabilities, $\mathrm{I}=$ Inventory, $\mathrm{CA}=$ Current Assets, and $\mathrm{TA}=$ Assets .

The moderating variable uses a dummy variable with code 0 for non-financial constraints (NFC) and 1 for financial constraints (FC). The measurement of variables uses the steps of Hidayat [47] in classifying NFC and FC firms. There are four stages of classification namely by looking at dividend policy, cash flow, investment opportunities, and debt levels. The initial classification is based on dividend policy (DPR). Some studies use dividend payout ratios [38, 42]. Companies with low dividends are in the FC category, while companies with high dividends are in the NFC category. There are two possible reasons why companies pay low dividends. First, companies face expensive external funding sources because of the information asymmetry that uses most of the profits to finance their investments rather than paying high dividends. Second, the company does not get enough profit to pay dividends. Companies that pay dividends are included in the NFC category, while companies that do not pay dividends are included in the FC category. Companies that are in the FC category might not be able to pay dividends because they cannot afford to pay dividends, but the possibility of funds owned is used for other purposes such as for investment, so the second classification is needed by looking at cash flow.

Companies that are in the NFC category if the company's BMV ratio is lower than the average BMV ratio of the entire sample, and if it is higher will be included in the FC category. Furthermore, to be more convincing and obtain more accurate results in classifying NFC and FC firm, companies in the financially constrained category in the third classification are followed by the fourth classification by looking at the company's debt. The fourth classification uses the level of debt. Companies that have high levels of debt (DER) tend to be difficult to access external funding sources and conversely companies that have low levels of debt tend to be easier to access external funding sources [50,51]. For this reason, companies that have a debt ratio that is lower than the average debt ratio of all samples will be categorized as NFC firms, while if companies have higher debt ratio will be categorized as FC firms. In the second classification, as used by Moyen [37], companies that have cash flow greater than the average cash flow of all samples are categorized as NFC, while companies that have cash flow are smaller than the average cash flow. The sample is categorized as FC. Companies with large cash flows tend not to experience constraints in funding and vice versa companies with small cash flows tend to experience funding constraints. To get an accurate classification of NFC and FC companies, companies that are categorized as financially constrained in the second classification are followed by a third classification. The third classification uses company investment opportunities. Categorizing NFC and FC firm uses the book to market ratio (BMV). This proxy is also used by Hovakimian and Titman [52].

\subsection{Analysis Technique}

Because the moderating variable is a dummy variable, this study uses sub-group analysis. According to Sugiono [53], the selection of a moderating variable test analysis tool can be seen from the nature of the predictor variable and the moderator variable. In sub-group analysis, the sample is divided into 2 groups based on the categories of moderator variables. After that, 3 regression equation models will be formed, the first is the equation model for all samples and the second and third equations are the models for each category.

$$
\begin{gathered}
\mathrm{VF}_{\mathrm{it}}=\alpha_{0}+\alpha_{1} \mathrm{CSDI}_{\mathrm{it}}+\mathrm{e}_{\mathrm{it}} \text { (regression model for full } \\
\text { sample) } \\
\mathrm{VF}_{\mathrm{it}}=\beta_{0}+\beta_{1} \mathrm{CSDI}_{\mathrm{it}}+\mathrm{e}_{\mathrm{it}} \text { (regression model for NFC } \\
\text { sample) }
\end{gathered}
$$

$\mathrm{VF}_{\mathrm{it}}=\lambda_{0}+\lambda_{1} \mathrm{CSDI}_{\mathrm{it}}+\mathrm{e}_{\mathrm{it}}($ regression model for FC sample)

Note:

$\mathrm{VF}_{\text {it }} \quad$ : Firm value

CSDI $_{i t}$ : CSR Disclosure Index firm i at year $t$

$\alpha_{0}, \beta_{0}, \lambda_{0}$ : the intercept or constant

$\alpha_{1}, \beta_{1}, \lambda_{1}$ : the estimated coefficient of variables

$e_{i t}$ : the error term for each firm $i$ at year $t$.

To determine whether the variable functions as a moderating variable, a chow-test is performed. According to Ghozali [54], the chow-test is a tool for examining the test for equality of coefficients or the similarity coefficient test found by Gregory Chow. If it is proven that the regression coefficient between sub-groups is significantly 
different, it can be concluded that the variable is moderation. Before testing a hypothesis that uses a regression model, it must first be tested classic assumptions namely normality, heteroscedasticity, autocorrelation and multicollinearity. Hypothesis decision-making is done by calculating the value of $\mathrm{F}$. However, if the calculated $\mathrm{F}$ value is smaller or equal to the $\mathrm{F}$ table then the null hypothesisis accepted, and vice versa.

\section{Results}

\section{Descriptive Statistics}

Table 1 shows that average Tobin's $Q$ value is 1.36 , which means the sample companies are rated well by the market. Whereas based on the company's financial constraints, it appears that firms that have financial constraints are fundamentally lower than firms with non-financial constraints. This illustrates that financial constraints are a fundamental problem of the company that can affect the market's assessment of the company's prospects. The same pattern also occurs in CSR disclosures. It can be seen in Table 1 that the level of disclosure of companies experiencing financial constraints is lower than companies that have non-financial constraints. This shows that financial constraints are considered as bad news for the market so the company limits the scope of information disclosed to the market.

\section{Testing Statistical Assumptions}

The initial step is to examine the main assumptions underlying this regression model. A summary of the results of the classic assumptions can be seen in Table 2 . The normality test results show that the confounding variable in this regression model has no normal distribution as indicated by the Kolmogorov Smirnov value of 4.979 and significant 0.00 . The results of the classic assumption test also indicate that there is an autocorrelation problem. This problem is shown from the calculated DW value of 1.040 which is smaller than the $\mathrm{dL}$ value of 1.77252 .

Based on the results of the classic assumptions, it is known that the regression model still has problems with normality and autocorrelation. Therefore, we took the treatment step by removing the outlier and then changing the regression equation into a semi-log form. The first step is detecting outlier data. According to Ghozali [54], detection of outliers can be done by determining the boundary values that are categorized as outliers. If the sample is small (less than 80), then the standard score with a value of $\geq 2.5$ is declared an outlier. For a large sample of standard scores stated outlier if the value is in the range of 3 to 4 . After we detect outlier data, the next step is to maintain or discard the outlier data. Basically, outliers should be maintained if the outliers are indeed representations of the population. However, we must remove the outlier if the outlier data do not represent observations in the population. Outlier detection results show that there are 21 outlier data that must be discarded. As a result, the number of initial observational data was 264 to 243 data.

Ghozali [54] states that to treat this classic assumption, the regression model is changed in a semi-log form. First, change the equation to the left (the dependent variable) into a natural logarithmic form ( $\mathrm{Ln}$ ) and the independent variable remains unchanged. Second, the dependent variable remains unchanged while the variable on the right (the independent variable) is transformed into a natural logarithmic form (Ln). In this research, the regression model is treated by changing the dependent variable with a natural logarithm ( $\mathrm{Ln}$ ) because the independent variable has a dummy variable. Hence, we chose the company value variable to be transformed into LnNP. The results of the transformation have an impact on the reduction in 12 data so that the final data becomes 231 observational data. Table 2 shows that after the outlier treatment and transformation of the data, all classical assumptions were fulfilled.

Table 1. Descriptive statistics

\begin{tabular}{ccccccc}
\hline Variable & Minimum & Maximum & Mean & Standart Deviation & Mean NFC & Mean FC \\
\hline Firm value (FV) & 0.1247 & 13.6945 & 1.3664 & 1.5568 & 1.5612 & 0.8796 \\
CSDI & 0.0000 & 0.7308 & 0.2223 & 0.1420 & 0.2447 & 0.1662 \\
Data observation & & & & 165 & 66 \\
\hline
\end{tabular}

Table 2. Classic assumption testing

\begin{tabular}{cccc}
\hline Classic assumption & Test & Before treatment & After treatment \\
\hline Normality & & Value & Value \\
Autocorrelation & Kolmogorov Smirnov (Z) & $4.979 *$ & 0.872 \\
Heteroscedasticity & Durbin Watson (DW) & 1.040 & 1.874 \\
\hline
\end{tabular}

Note: * denote significance at 5 percent, No autocorrelation detection if $1.77525<\mathrm{DW}<2.22475$ 


\section{Regression Result and Hypothesis Test}

The results show that CSR disclosure is more influential in firm value in FC companies compared to NFC companies. The explanation is that there is information asymmetry in external funding so that external funding such as debt is more expensive than internal funding, which results in FC companies having less access to external funding sources. This finding shows that CSR disclosure is more sensitive to firm value when the company has financial constraints. Table 3 presents the regression analysis output for the three regression models. The regression equations are as follows:

$$
\begin{gathered}
\operatorname{LnVF}_{\mathrm{it}}=-0.352+1.192 \mathrm{CSDI} \text { (regression model full } \\
\text { sample) } \\
\mathrm{LnVF}_{\mathrm{it}}=-0.233+1.100 \mathrm{CSDI} \text { (regression model NFC } \\
\text { sample) } \\
\mathrm{LnVF}_{\mathrm{it}}=-0.350-0.262 \mathrm{CSDI} \text { (regression model FC } \\
\text { sample) }
\end{gathered}
$$

\begin{tabular}{|c|c|c|c|c|c|}
\hline $\begin{array}{c}\text { Regression } \\
\text { Model }\end{array}$ & $\mathbf{N}$ & $\mathbf{a}$ & b & t-statistic & Sig. \\
\hline Full sample & 231 & -0.352 & 1.192 & 3.045 & $0.003^{* *}$ \\
\hline $\begin{array}{c}\text { Sample } \\
\text { NFC }\end{array}$ & 165 & -0.233 & 1.100 & 2.429 & $0.016^{* * *}$ \\
\hline Sample FC & 66 & -0.350 & -0.262 & -0.293 & 0.771 \\
\hline
\end{tabular}

Table 3. Sub-group regression result

Note: *,**,*** denote significance at 10 percent, 5 percent, and 1 percent level.

The coefficient of the regression equation for all samples shows a positive direction. The same output is also seen for the NFC sample regression equation. These findings indicate that the higher the disclosure of CSR, the greater the value of the firm. Meanwhile, the FC sample regression equation coefficient showed that no specific pattern can be revealed for the FC sample, which means that if the company discloses more CSR, then the value of the firm will be smaller. Seen from the direction of the coefficient, it appears that the coefficient value of the NFC sample regression equation has the same direction as the coefficient of the whole sample regression equation. But the direction of the $\mathrm{FC}$ sample regression equation coefficient is opposite to the NFC sample regression equation coefficient. These results indicate that the condition of financial constraints can change the direction of the influence of CSR disclosure on firm value.

Table 4. Summary of Sub-Group Regression Model

\begin{tabular}{cccccc}
\hline $\begin{array}{c}\text { Regression } \\
\text { Model }\end{array}$ & N & $\begin{array}{c}\text { R } \\
\text { square }\end{array}$ & F-statistic & Sig. & SSR \\
\hline $\begin{array}{c}\text { Full sample } \\
\text { Sample }\end{array}$ & 231 & 0.039 & 9.273 & 0.003 & 162.891 \\
$\quad$ NFC & 165 & 0.035 & 5.902 & 0.016 & 124.700 \\
Sample FC & 66 & 0.001 & 0.086 & 0.771 & 31.539 \\
\hline
\end{tabular}

Table 4 shows that the $\mathrm{R}$ square value of the NFC sample model is greater than that of the FC sample model. These results indicate that the contribution of CSR disclosure on firm value is greater in non-financial constraint firms than in financial constraint firms. Table 5 reports the output $\mathrm{F}$ value is 4.831958 while the $\mathrm{F}$ table is 3.882386. These findings indicate that the calculated $\mathrm{F}$ value is greater than the $\mathrm{F}$ table which means the equation of regression between the NFC and FC subgroups is significantly different. The research hypothesis is supported. Hence, it can be concluded that CSR disclosure has an effect on firm value in NFC firms compared to FC firms or financial constraints have a moderating effect.

Table 5. Result of Chow Test

\begin{tabular}{cccc}
\hline & Equation & Value & Result \\
\hline SSRT & & 162.891 & \\
SSR1 & & 124.700 & \\
SSR2 & & 31.539 & \\
N1 & & 165 & \\
N2 & & 66 & \\
k & & 2 & \\
SSRG & SSR1+SSR2 & 156.2393 & \\
F & $($ SSRT - SSRG $) / \mathrm{k}$ & $4.831958 *$ & supported \\
value & SSRG $/(\mathrm{N} 1+\mathrm{N} 2-2 \mathrm{k})$ & & \\
F table & "=FINV $(0,05 ; 1 ; 229) "$ & 3.882386 & \\
\hline
\end{tabular}

Note: * denote significance at 5 percent

\section{Discussion}

Companies that increasingly disclose CSR activities and do not have financial constraints will increase firm value. As shown in Figure 1, the value of the firm will decrease when companies experiencing financial limitations issue CSR disclosures. The results showed a regression line pattern between groups of nonfinancial and financial constraints. Figure 1 reveals the different patterns between the two sample groups. Companies that increasingly disclose CSR activities and do not have financial constraints will increase firm value. Conversely, the value of the firm will decrease when companies experiencing financial constraints publish CSR disclosures.

CSR disclosure can be a signal of a company's long-term liquidity. CSR activities although social must be managed in a business manner and require management commitment. This means that if CSR activities are a form of corporate responsibility and concern for the environment, it must be managed professionally. CSR activities are long-term programs that require planned strategy, management and funding if the objectives of CSR activities are for environmental and community awareness. Companies that can consistently maintain the program in the long run will be good news for investors or the public. High CSR performance is related to better stakeholder care, which limits opportunistic behavior in the short term $[32,55]$. 


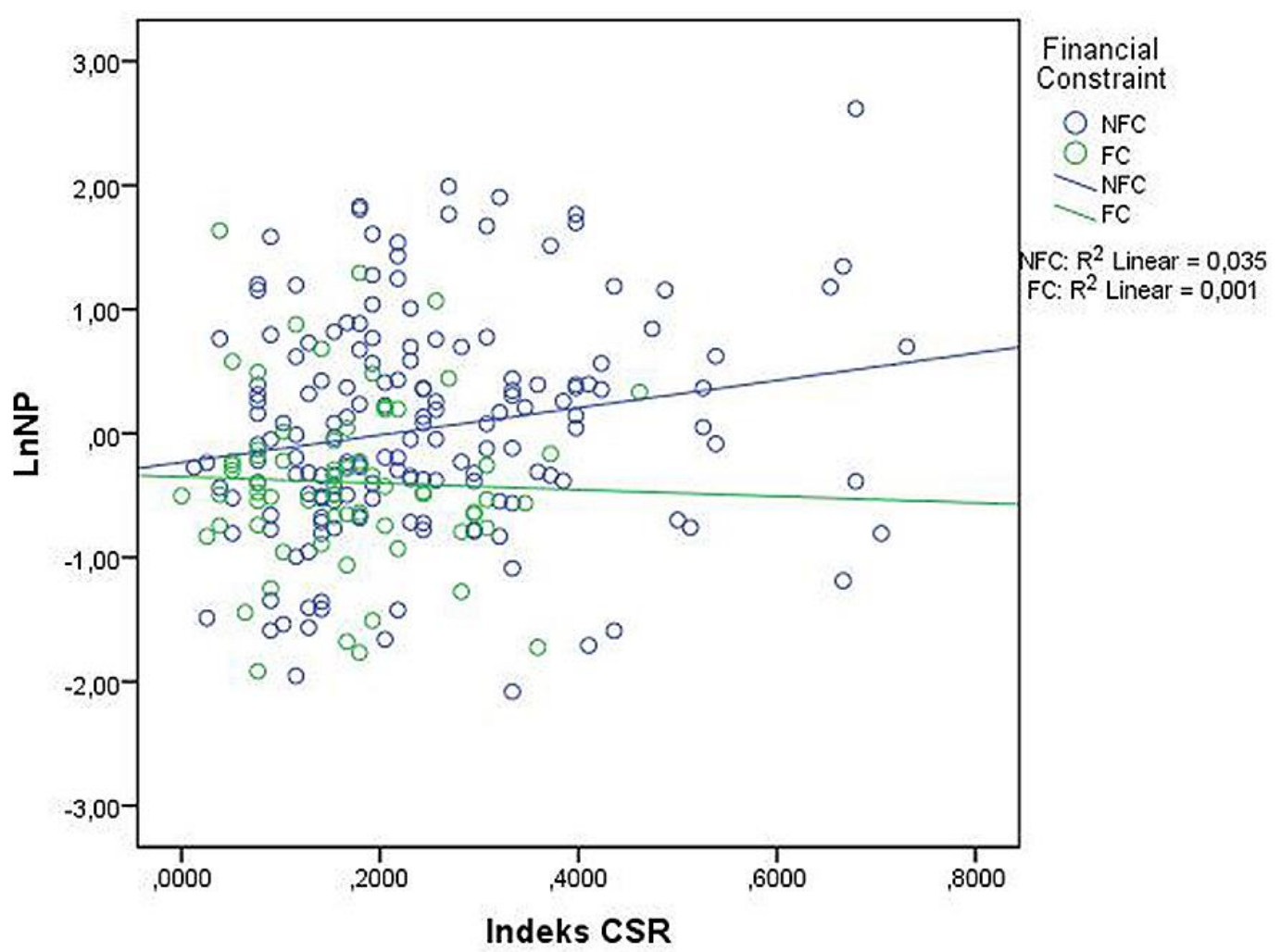

Figure 1. Regression models pattern

If CSR activities are only used as cosmetics to manipulate company conditions to attract investors, in the long run these activities will actually reduce the company's value. Management often has opportunistic behavior that is detrimental to the company in the long run. Short-term CSR activities are fund-giving or even ceremonial that spend a lot of money and increase public attention. Management that has opportunistic behavior like that will tend to create CSR programs that are short-term and costly (without cost) without any real effect on receiving funds in the future. This is evidenced by the results of research in which companies that increase CSR disclosure but experience limited funds because the value of the company to decreases [56-58]. Companies with better CSR performance prefer to disclose their CSR activities to the market to signal their long-term focus and be a differentiator with others [31, 32].

\section{Conclusion}

This study aims to examine that the impact of CSR disclosure on firm value will be different if the company experiences financial constraints. The results showed that CSR disclosure had a positive effect on firm value in companies that did not experience financial constraints. But the opposite results occur when tested on companies with financial constraints. Based on the results of the analysis it can be said that financial constraints are moderating variables in the relationship between CSR disclosure and firm value. Other findings show that financial constraints have different effects on firm value, so it can be said that CSR disclosure is a signal of liquidity for external parties.

This research can be expanded by adding types of industries and extending the research period. Also, analysis tools can be developed by using Moderated Regression Analysis (MRA) with ratio-scale moderation variables such as potential bankruptcy. The signal of liquidity can also be seen from the condition of the company's bankruptcy, namely Altman's z-score bankruptcy measure.

\section{REFERENCES}

[1] Ioannou I., Serafeim G, "The consequences of mandatory corporate sustainability reporting: Evidence from four countries," Mimeo: London Business School, 2016.

[2] KPMG., "The KPMG Survey of Corporate Responsibility Reporting 2013,” KMPG International Cooperative, 2013.

[3] Gray R., Kouhy R., Lavers S., "Corporate social and environmental reporting: a review of the literature and a longitudinal study of UK disclosure," Accounting, Auditing \& Accountability Journal, vol. 8, no. 2, pp. 47-77, 1995.

[4] Hill R. P., Ainscough T., Shank T., Manullang D., "Corporate social responsibility and socially responsible investing: A global perspective," Journal of Business Ethics, vol. 70, no. 2, pp. 165-174, 2007. 
[5] Bajic S., Yurtoglu B., "Which aspects of CSR predict firm market value?" Journal of Capital Markets Studies, vol. 2, no. 1, pp. 50-69, 2018.

[6] Kumarasinghe S., Will M., Hoshino Y., "Enhancing performance by disclosing more: some evidence from Japanese companies," Pacific Accounting Review, vol. 30, no. 1, pp. 110-128, 2018.

[7] Crisostomo V. L., Freire F. de S., Vasconcellos F. C. de., "Corporate social responsibility, firm value and financial performance in Brazil," Social Responsibility Journal, vol. 7, no. 2, pp. 295-309, 2011.

[8] Jitmaneeroj B., "A latent variable analysis of corporate social responsibility and firm value," Managerial Finance, vol. 44, no. 4, pp. 478-494, 2018.

[9] Gunawan B., Utami S. S., "Peranan Corporate Social Responsibility Dalam Nilai Perusahaan,” Jurnal Akuntansi Dan Keuangan, vol. 7, no. 2, pp. 174-185, 2008.

[10] Rustiarini W. N., "Pengaruh Corporate Governance pada Hubungan Corporate Social Responsibility dan Nilai Perusahaan. In Proceedding Simposium Nasional Akuntansi XIII," Purwokerto: Simposium Nasional Akuntansi XIII, 2010.

[11] Murwaningsari E., "Hubungan Corporate Governance, Corporate Social Responsibilities dan Corporate Financial Performance Dalam Satu Continuum," Jurnal Akuntansi Dan Keuangan, vol. 11, no. 1, pp. 30-41, 2009.

[12] Nurlela R., Islahuddin., "Pengaruh Corporate Social Responsibility Terhadap Nilai Perusahaan Dengan Prosentase Kepemilikan Sebagai Variabel Moderating," In Simposium Nasional Akuntansi XI. Pontianak: Simposium Nasional Akuntansi, 2008.

[13] Tjia O., Setiawati L., "Effect of CSR Disclosure to Firm Value: Study for Banking Industry in Indonesia," World Journal of Social Sciences, vol. 2, no. 6, pp. 169-178, 2012.

[14] Fakhimuddin M., Khasanah U., Trimiyati R., "Database Management System in Accounting: Assessing the role of Internet Service Communication of Accounting System Information," Research Horizon, vol. 1, no. 3, 2021.

[15] Lee S., Park S., "Do socially responsible activities help hotels and casinos achieve their financial goals?" International Journal of Hospitality Management, vol. 28, pp. 105-112, 2009.

[16] Liu X., Zhang C., "Corporate governance, social responsibility information disclosure, and enterprise value in China," Journal of Cleaner Production, vol. 142, pp. 1075-1084, 2017.

[17] Nekhili M., Nagatib H., Chtioui T., Rebolledo C., "Corporate social responsibility disclosure and market value: Family versus nonfamily firms," Journal of Business Research, vol. 77, pp. 41-52, 2017.

[18] Fazzari S. M., Hubbard G. R., Petersen., B. C., "Financing constraints and corporate investment," Brookings Papers on Economic Activity, vol. 1, 141-195, 1988.

[19] Vogt S. C., "The Cash Flow/Investment Relationship: Evidence from U.S. Manufacturing Firms," Financial Management, vol. 23, pp. 3-20, 1994.
[20] Kaplan S. N., Zingales L., "Do investment-cash flow sensitivities provide useful measures of financing constraints? The Quarterly Journal of Economics, vol. 112, no. 1, pp. 169-215, 1997.

[21] Cleary S., "The Relationship Between Firm Investment and Financial Status," The Journal of Finance, vol. 54, no. 2, pp. 673-692, 1999.

[22] Almeida H., Campello M., Weisbach M., "The cash flow sensitivity of cash," Journal of Finance, vol. 59, pp. 17771804,2004

[23] Hoshi T., Kashyap A., Scharfstein D., "Corporate Structure, Liquidity, and Investment: Evidence from Japanese Industrial Groups," Quarterly Journal of Economics, vol. 106, no. 1, pp. 33-60, 1991.

[24] Shapiro C., "Premiums for high quality products as returns to reputation," Quarterly Journal of Economics, vol. 98, no. 4, pp. 659-679, 1983.

[25] Ball R., Brown., "An Empirical Evalution of Accounting Income Numbers," Journal of Accounting Research, vol. 6, pp. 159-178, 1968.

[26] Andayani W., Mwangi J. K., Sadewo D., Atmini S., "Corporate Social Responsibility, Good Corporate Governance and the Intellectual Property: An External Strategy of the Management to Increase the Company's Value," SSRN Electronic Journal, vol. 40, 2011. https://doi.org/10.2139/ssrn.1327513

[27] Orlitzky M., Schmidt F. L., Rynes S. L., "Corporate Social and Financial Performance: A Meta-Analysis," Organization Studies, vol. 24, no. 3, pp. 403-441, 2003.

[28] Brown T. J., Dacin P. A., "The Company and The Product: Corporate Associations and Consumer Product Responses," Journal of Marketing, vol. 61, no. 1, pp. 68-84, 1997.

[29] Brown W., Helland E., Smith J., "Corporate Philanthropic Practices," Journal of Corporate Finance, vol. 12, no. 5, pp. 855-877, 2006.

[30] Cheng B., Ioannou I., Serafim G., "Corporate Social Responsibility and Access to Finance," Strategic Management Journal, vol. 35, pp. 1-23, 2014.

[31] Dhaliwal D., Li O. Z., Tsang A. H., Yang Y. G., "Voluntary Non-Financial Disclosure and The Cost of Equity Capital: The Case of Corporate Social Responsibility Reporting," The Accounting Review, vol. 86, no. 1, pp. 59-100, 2011.

[32] Benabou R., Tirole J., "Individual and Corporate Social Responsibility," Economica, vol. 77, no. 305, pp. 1-19, 2010.

[33] Fama E.F., "The Effect of a Firm's Investment and Financing Decisions on the Welfare of it Security Holders," American Economics Review, vol. 68, pp. 272-284, 1978.

[34] Theodoulidis B., Diaz D., Crotto F., Rancati E., "Exploring corporate social responsibility and fi nancial performance through stakeholder theory in the tourism industries," Tourism Management, vol. 62, pp. 173-188, 2017.

[35] Villarón-Peramato O., García-Sánchez I.-M., Martínez-Ferrero J., "Capital structure as a control mechanism of a CSR entrenchment strategy," European Business Review, vol 30, no. 3, pp. 340-371, 2018. 
[36] Modigliani F., Miller M. H., "The Cost of Capital, Corporation Finance, and the Theory of Investment. American Economics Review, vol. 48, pp. 461-297, 1958.

[37] Moyen N., "Investment-Cash Flow Sensitivities: Constrained versus Unconstrained Firms," Journal of Finance, vol. 54, no. 5, pp. 2061-2092, 2004.

[38] Agung J., "Financial Constraint, Firms Investment and the Channels of Monetary Policy in Indonesia," Apllied Economics, vol. 32, pp. 1637-1646, 2000.

[39] Kristianti R. A., "Pengaruh Likuiditas Terhadap Keputusan Investasi Aktiva Tetap pada Perusahaan yang Dikelompokkan dalam Financially Constraints," Yogyakarta: Universitas Gadjah Mada, 2003.

[40] Deni A., Riswandi R., Sobar A., Hamidi D. Z., Permadi I., "The effect of product turnover on company performance of SMEs,"Research Horizon, vol. 1, no. 3, 2021.

[41] Hermeindito., "Asymmetry Information and Management Control: Sensitivity Analysis of Investment and Leverage on Selecting Source of Financing," Yogyakarta: Universitas Gajah Mada, 2004.

[42] Prasetyantoko A., "Financing Constraint and Firm-Level Investment Following a Financial Crisis in Indonesia," SSRN Electronic Journal, Vol. 33, 2011. https://doi.org/10.2139/ssrn.1014326.

[43] Jensen M., Meckling W., "Theory of the Firm: Managerial Behavior, Agency Costs and Ownership Structure,” Journal of Financial Economics, vol. 3, no. 4, pp. 305-360.

[44] Chan L. K., Chen N., "Structural and Return Characteristics of Small and Large Firms," Journal of Finance, vol. 46, pp. 1467-1484, 1991.

[45] Fama E. F., French K. R., "The Cross-Section of Expected Stock Returns," Journal of Finance, vol. 47, pp. 427-465, 1992.

[46] Bhandari A., Javakhadze D., "Corporate social responsibility and capital allocation efficiency," Journal of Corporate Finance, vol. 43, pp. 354-377, 2017.

[47] Hidayat R., "Keputusan Investasi dan Financial Constrains: Studi Empiris pada Bursa Efek Indonesia," Buletin Ekonomi Moneter Dan Perbankan, pp. 457-479, 2010.
[48] Sayekti Y., Wondabio L. S., "Pengaruh CSR Disclosure Terhadap Earning Response Coefficient (Suatu Studi Empiris Pada Perusahaan yang Terdaftar Di Bursa Efek Jakarta)," Makasar: In Simposium Nasional Akuntansi, 2007.

[49] Anderson E. W., Fornell C., Mazvancheryl S. K., "Customer satisfaction and shareholder value," Journal of Marketing, vol. 68, no. 4, pp. 172-185, 2004.

[50] Bukhori A., "The Role of Youth in Managing Educational Startup: Case Study of PrivatQ startup," Research Horizon, vol. 1 , no. 2,2021

[51] Srivastava R. K., Shervani T. A., Fahey L., "Market-based assets and shareholder value: A framework for analysis," Journal of Marketing, vol. 62, no. 1, pp. 2-18, 1998.

[52] Hovakimian G., Titman S., "Corporate Investment with Financial Constraints: Sensitivity of Investment to Funds from Voluntary Asset Sales," Journal of Money, Credit, and Banking, vol. 38, no. 2, pp. 357-374, 2006.

[53] Sugiono., "Konsep, Identifikasi, Alat Analisis dan Masalah Penggunaan Variabel Moderator," Jurnal Studi Manajemen \& Organisasi, vol. 1, no. 2, pp. 61-71, 2004.

[54] Ghozali I., "Aplikasi Analisis Multivariate dengan Program SPSS (7th ed.)," Semarang: Badan Penerbit Universitas Diponegoro, 2013.

[55] Alyousef L., Alsughayer S., "The Relationship between Corporate Governance and Voluntary Disclosure: The Role of Boards of Directors and Audit Committees," Universal Journal of Accounting and Finance, vol. 9, no. 4, pp. 678-692, 2021. DOI: 10.13189/ujaf.2021.090414.

[56] Servaes H., Tamayo A., "The impact of corporate social responsibility on firm value: The role of customer awareness.," Management science, vol. 59, no. 5, pp. 1045-1061, 2013.

[57] Jo H., Harjoto M. A., "Corporate governance and firm value: The impact of corporate social responsibility," Journal of business ethics, vol. 103, no. 3, pp. 351-383, 2011.

[58] Buchanan B., Cao C. X., Chen C., "Corporate social responsibility, firm value, and influential institutional ownership," Journal of Corporate Finance, vol. 52, pp. 73-95, 2018. 